\title{
What we can learn from semiotics, systems theory, and theoretical biology to understand religious communication
}

\section{Volkhard Krech ${ }^{1}$}

\begin{abstract}
If religion is a socio-cultural meaning system as part of the socio-cultural sphere, then how does it relate to mental, organic, and physical processes that belong to the environment of religion? The article contributes to answering this question by referring to semiotics, systems theory, and theoretical biology. The starting point is understanding religious evolution as a co-evolution to societal evolution, namely, as one of the latter's internal differentiations. In turn, societal evolution is a co-evolution to mental, organic, and physical evolution. These evolutionary spheres mutually constitute one another's environments. The eigenstate of the socio-cultural sphere consists of language activated via communication. Language is the replicator of socio-cultural processes corresponding to the function of the genome in organic processes. The differentiation of spheres in general evolution concerns respective organic, mental, and socio-cultural substrates, while the substrate-neutral structure of the two evolutionary dimensions of organic and societal processes, including religion, is revealed as semiotic patterns that organic and societal processes have in common. Organic and religious processes of generating information are isomorphic. Thus, semiosis mediates between religious communication and its environment.
\end{abstract}

Keywords: semiotics of religion; biosemiotics of religion; systems theory of religion; religious evolution; religious communication

"[...] all human cognition begins with intuitions, goes from there to concepts, and ends with ideas." (Kant 1998[1781]: 622) "The greatest difficulty in these investigations [i.e. of geometry] has been, and still is, that so long as the only method of geometry was the intuitive method taught by Euclid, it was all too easy to intermix results of everyday experience,

1 Ruhr University Bochum, CERES, Universitätsstrasse 90a, D-44789 Bochum, Germany. E-mail: volkhard.krech@rub.de. 
as apparent necessities of thought, with the logical development of concepts." (Helmholtz 1977[1868]: 4)

"[...] throw away the matter and keep the underlying organization." (Louie 2006: 36)

\section{Introduction ${ }^{2}$}

The relation between nature and the socio-cultural sphere in general, as well as religion in particular, belongs to the most challenging topics in science. Dual Inheritance Theory (DIT), also known as the approach of gene-culture co-evolution, conceptualizes genetic and socio-cultural evolution as two differentiated, but related processes (see., e.g., Fisher, Ridley 2013; Richerson, Boyd 2005). From a scientific perspective, socio-cultural evolution is part of natural evolution, i.e. the evolution as described by physics, chemistry, and biology. However, DIT has to consider the fact that the semantics of nature and culture are differentiated within society. Nature and the socio-cultural sphere do not constitute an ontological dualism, but an epistemological difference. Thus, the distinction of nature and culture is a re-entry within societal communication. ${ }^{3}$ Against the background of the distinction between nature and culture, religion can be described both as a natural and a socio-cultural phenomenon. As Feierman (2013: 257) notes,

[...] biology has also modestly contributed something to our understanding of certain aspects of religious subjectivity by a new field of functional brain scanning [...] in which areas of brain that are metabolically active during such things as prayer and feelings of transcendence can be studied [...].

However, the semantics of religious experience is subject to socio-cultural communication. In other words: religion proceeds under the condition of metabolically active areas of the brain as its physical and biochemical substrate, but - being part of the socio-cultural reality -, religion is not a physical and biochemical process only. From the perspective of physics, chemistry, and biology, "religion is natural as opposed to supernatural, [...] it is a human phenomenon composed of events, organisms, objects, structures, patterns, and the like that all obey the laws of physics or biology, and hence do not involve miracles" (Dennett 2006: 25). From a social scientific perspective, religion is based on physical and organic processes, but, in addition to that, it is a meaningful socio-cultural phenomenon. The

2 I am thankful to Lilith Apostel for a close reading of the manuscript and helpful comments.

3 A re-entry means that a distinction is copied into one side of the distinction (SpencerBrown 1979[1969]: 69-77). 
socio-cultural sphere in general and religion in particular structure matter and energy differently than it is explained by physics, chemistry, biology, and cognitive science. However, there is an isomorphism between the structures of organic processes and those of the socio-cultural sphere including religion, as will be shown and explained in the following. Among several topics, DIT has been applied to the study of religion. In the standard model of the evolutionary approach to religion, religion is conceptualized as an interplay between mental processes, material objects, and socio-cultural communication systems (Martin, Wiebe 2017; Bulbulia et al. 2013). Nevertheless, the way the mentioned components relate to one another remains, as yet, elusive (Bulbulia et al. 2013: 385).

This article proceeds from DIT and understands communicatively activated language (including religious language) ${ }^{4}$ as the replicator of socio-cultural processes (including religion as a societal subsystem) analogous to the genome in organic evolution (Pagel 2017). DIT is enhanced by means of semiotics (CP 3), social systems theory (Luhmann 1995), and theoretical biology (Rosen 1991). General evolution is understood as differentiated into physical, organic, mental, and sociocultural spheres. All of the evolutionary spheres are organized in systems and are emergent, i.e., none of them can be reduced to another one (Emmeche, Køppe, Stjernfelt 2000); they constitute their mutual environment. The socio-cultural sphere is conceptualized as communication that

[...] is an emergent reality, a state of affairs sui generis. It arises through a synthesis of three different selections, namely, selection of information, selection of the utterance of this information, and a selective understanding or misunderstanding of this utterance and its information. (Luhmann 1992: 252)

Social communication possesses an emergent eigenstate, that is differentiated from consciousness in mental systems, although related to it (Luhmann 1992). This differentiation structurally equals the differentiation between cognition and feelings on the one hand, and other mutually coordinated neurophysiological processes, such as unconscious perception, as environmental correlates in the brain on the other hand (Tononi 2012). The same holds true for the differentiation between organic processes, such as signalling and self-sustaining processes in the biosphere on the one hand, and physical processes as their environment on the other hand (Kauffman 2008: 31-43). The eigenstate of each evolutionary sphere means that the continuum of matter and energy is interrupted. Interruption in the form of drawing boundaries is essential to processing information and building

4 Communicatively activated language can be understood in the sense of Saussure's parole (speech) in contrast to langue (Saussure 2011[1916]: 13). 
complexity in all higher-level systems (Luhmann 1995: 29). Semiosis, i.e. "the triadic process by which a first determines a third to refer to a second to which itself refers" (Deledalle 2000: 18), is the interface that bridges the boundaries between the different evolutionary spheres and their environment from within respective semiotic systems.

Religious evolution is conceptualized as a co-evolution to societal evolution, i.e. as one of its internal differentiations. From this perspective, religion is a societal subsystem that copes with otherwise undetermined contingency by means of the binary code 'immanent/transcendent'. Society and religion as one of its subsystems proceed as autopoietic and self-referential communication systems (Luhmann 2012[1997], 2013). In its modern condition, society is differentiated into subsystems, including religion, that are autopoietic as well. Communication is based on semiotic processes (Cobley 2013), and biosemiotics shows that organisms also rely on semiosis (Emmeche, Kull 2011); e.g., the cell can be understood as a semiotic system (Barbieri 2007). In turn, cells and organisms become organized and coordinated through communication (Witzany 2010). Social communication, including religion, refers to its mental, organic, and physical environment via semiosis. Thus, the fields and topics of biology and linguistics are related to each other through semiotics (Velmezova, Kull, Cowley 2016). A synopsis of recent developments in general semiotics, systems theory, theoretical biology, and the study of religion reveals an isomorphism between religious sense generation and organic cell processes. In order to avoid misunderstandings, it should be noted that an isomorphism is not an identity between underlying sets of structures, but a correspondence between them (Burgess 2015: 108).

Isomorphic structures may be called 'like-structured' (that is, nearly enough, what isomorphic means etymologically), and may be said to exhibit a common 'structure' in a second sense of structure: what 'structures' in the first sense have in common when there is a 'structure-preserving' map between them. To prevent ambiguity, the second sense of 'structure' can be avoided in favor of the more technical term 'isomorphism type'. (Burgess 2015: 109)

A structure-preserving map is the result of drawing analogies. The structures to produce information that are shared by both organic and socio-cultural processes, including religion, are of an isomorphism type, as will be shown in the following. 


\section{Modelling the elementary socio-cultural semiotic system. Part I}

As is well known, according to Charles Sanders Peirce semiosis proceeds within the three categories of Firstness, Secondness and Thirdness. Floyd Merrell (1997: 167) summarizes the characteristics of the three categories as follows:

Firstness in its purest form, as a complement to Secondness and Thirdness, is reflexive, symmetrical, nontransitive, and self-contained. As such, the most that can be said of it is that it is as it is. [...] Secondness requires the existence of some other accompanied by dyadic relations of action-reaction, cause-effect, sequence-consequence, and statement-counterstatement: it entails 'What Is $\leftrightarrow$ Is Not' according to classical logical principles. [...] Thirdness, taking its cue from Secondness, is characterized by full-blown transitivity, radical asymmetry, temporality $[. .$.$] . Entailing the incessant push toward generality, or regularity, Thirdness$ embodies the effort - however futile - to bring processes to completion, to arrive once and for all at the plenitude of things.

According to the three categories, semiosis proceeds as a relation between a sign $\mathrm{S}$ within Firstness, an object $\mathrm{O}$ that a sign refers to within Secondness, and an interpretant $I$ that mediates the relation between the sign $S$ and its object $O$ within Thirdness. Thus, the structure of semiosis is always triadic: "[...] a sign stands for an object in some respect to some interpretant" (Parmentier 1994: 16).

Mathematics is of help in understanding semiosis, because it provides semiotics with fundamental axioms. In geometric terms, the three categories of semiosis constitute an infinite three-dimensional space (Fig. 1) - the semiosphere. ${ }^{5} \mathrm{~A}$

5 The concept of the semiosphere was introduced by Juri Lotman in 1984; see Lotman 2005 for the English reprint. However, the concept seems to be too broad and does not seem to take the differentiation of evolutionary levels and semiotic subsystems into account. According to Lotman, socio-cultural semiotic systems are "immersed" within the "semiotic space" and can only work through interaction with the semiotic space: "The unit of semiosis, the smallest functioning mechanism, is not the separate language but the whole semiotic space of the culture in question. This is the space we term the semiosphere. The semiosphere is the result and the condition for the development of culture" (Lotman 1990: 125). In other words: "semiosphere is a sphere of semiosis and an experience thereof; and as such, it is a prerequisite for any single act of communication to be interpreted as one" (Kotov, Kull 2011: 180). However, the concept of the semiosphere is interesting insofar as it takes self-reference of semiotic processes analogous to organic processes into account (Lotman 1990: 125; see also Nöth 2006). The concept of the socio-cultural semiosphere used here is understood in accordance with a theory of societal differentiation that is informed by systems theory (Luhmann 2012[1997], 2013). Thus, the socio-cultural semiosphere comprises the entire society that is differentiated into subsystems such as politics, economics, law, science, religion, arts, education, health and social aid system, 
triadic semiotic relation between a sign $\mathrm{S}$, an object $\mathrm{O}$ and an interpretant $\mathrm{I}$ can be described as having a single three-dimensional link that specifies its location in a three-dimensional space (Kilstrup 2015).

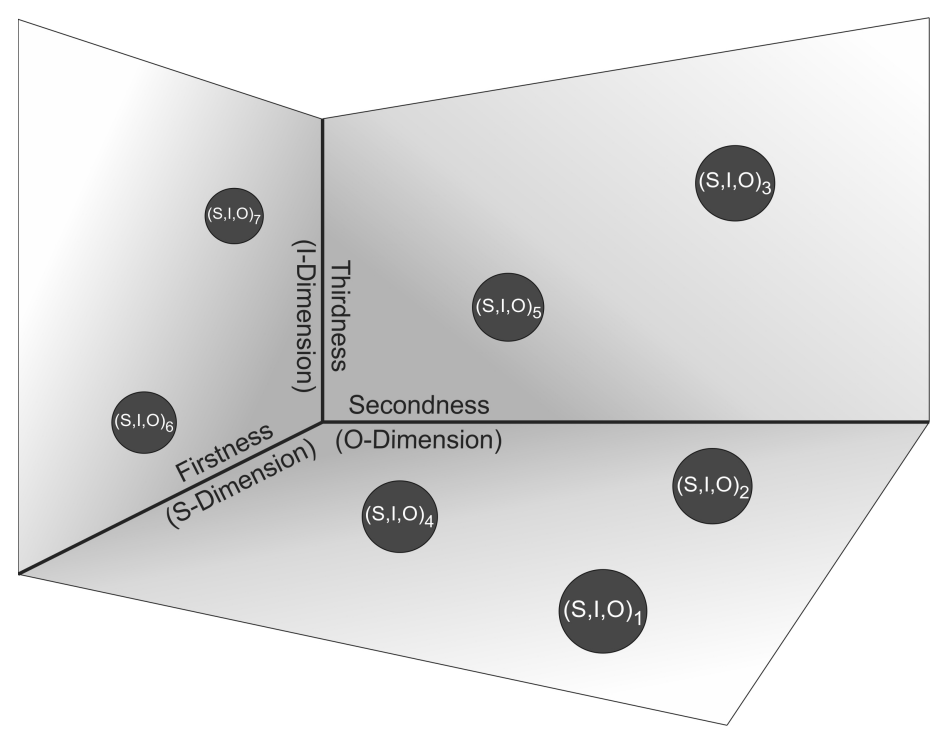

Figure 1. The three-dimensional space of the socio-cultural semiosphere (in accordance with Kilstrup 2015: 569). Each point designates an elementary semiosis with a triadic relation of a sign $\mathrm{S}$ within Firstness, an object $\mathrm{O}$ within Secondness, and an interpretant I within Thirdness.

One of the epistemological challenges in understanding semiotic processes in the socio-cultural sphere consists in answering the question of how a linear and directed connection between single, unconnected semiotic units with a triadic relation of $\mathrm{S}, \mathrm{O}$, and I can emerge and how infinite semiosis transforms into a finite and closed state of semiosis as is the case with socio-cultural semiotic systems. ${ }^{6}$

etc. These subsystems - like the entire socio-cultural semiosphere - are autopoietic, selfreferential and based on their own code.

6 Cell biology has to deal with a similar problem: "In the cell, the crucial point is that genes carry linear information whereas the function of proteins is determined by their threedimensional structure" (Barbieri 2015: 174). The solution that nature provides to this problem "is both simple and extraordinary. The linear information of a gene is used to assemble a linear sequence of amino acids, and then this polypeptide chain undergoes a folding process and assumes a specific three-dimensional form. It is as if one wrote the word 'apple' and then observed the word folding itself up and becoming a real apple" (Barbieri 2015: 174). 
Projective geometry helps to answer this question. It explains how elements in a three-dimensional space can connect to each other in a so-called projective plane. The smallest projective plane is the Fano plane named after the Italian mathematician Gino Fano (1871-1952). It consists of seven points and seven lines (Fig. 2a; the incircle is to be understood as a line as well). Three points are on a line, and three lines run through a point. Every two points define a line, and every two lines meet at a point (Gleason 1956).

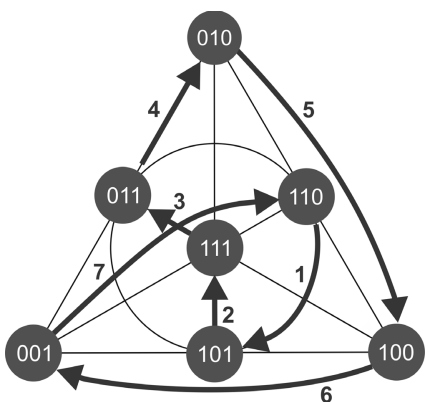

(a)

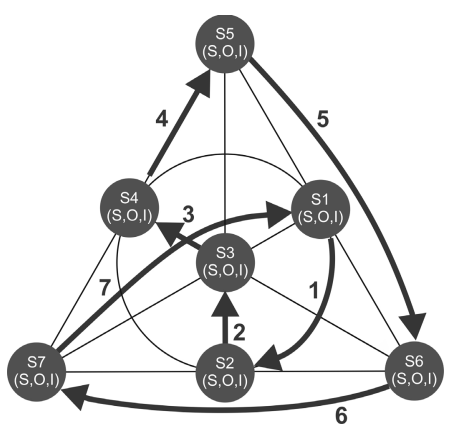

(b)

Figure 2. (a) Visualization of the Fano plane, in accordance with Polster (1998: 6) and provided with homogeneous coordinates as well as with possible directions of the Fano plane as a generating set. (b) shows the basic semiotic sequence as a generating set.

Using homogeneous coordinates, the seven points of the Fano plane may be labelled with the seven non-zero ordered triples of binary digits 001, 010, 011, $100,101,110$, and 111: For every two points $p$ and $q$, the third point on line $p q$ has the label formed by adding the labels of $p$ and $q$ modulo $2 .^{7}$ Thus, the points of the Fano plane correspond to the non-zero points of the finite vector space of dimension 3 over the finite field of order 2. If we exchange the non-zero ordered triples of binary digits with semiotic units consisting of a triadic relation between $\mathrm{S}, \mathrm{O}$, and I (Fig. 2b), we get the insight that a basic semiotic sequence needs seven semiotic units and seven relations in order to emerge from the three-dimensional, undirected semiosphere (Fig. 1). This in accordance with one of Peirce's semiotic

7 Modulo 2 addition is performed using an exclusive OR (xor) operation on the corresponding binary digits of each operand. The following equations describe the xor operation: $0+0=0$; $0+1=1 ; 1+0=1 ; 1+1=0$. 
axioms, namely that "the meaning of a sign is the sign it has to be translated into" (CP 4.132).

It might be easier to understand the Fano plane if we consider that it (however, trivially) fulfils the little Desargues theorem (Fig. 3).

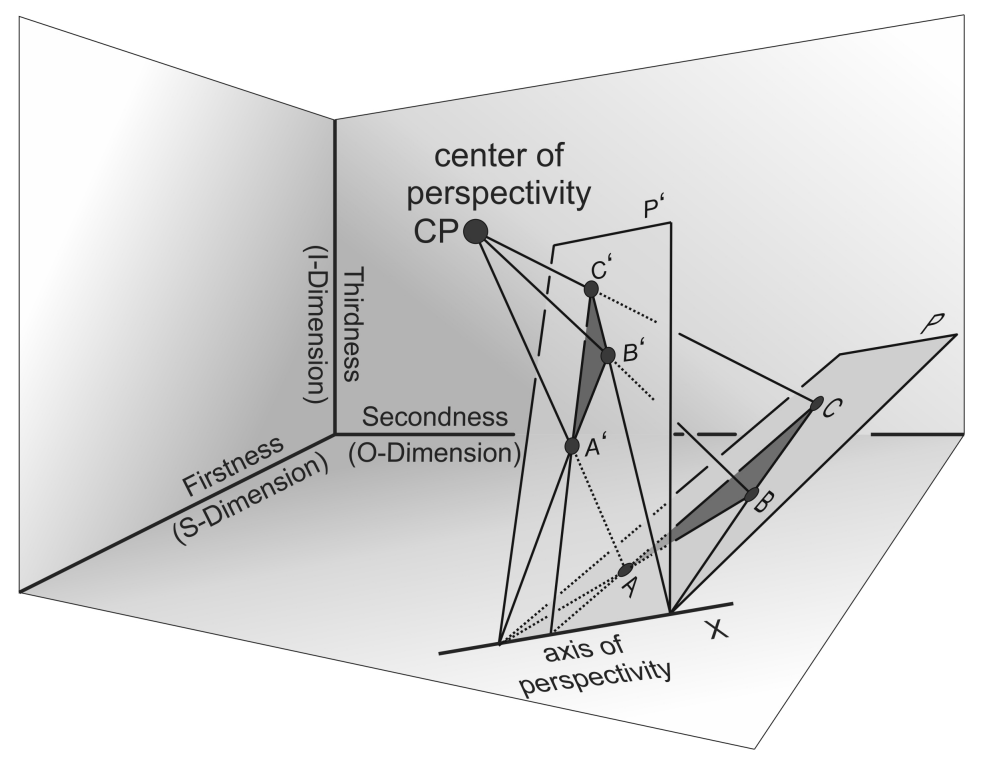

Figure 3. Depiction of the little Desargues theorem according to Kodokostas 2014: 2, embedded in the three-dimensional semiosphere, according to Kilstrup 2015: 569. A triangle with the points $\mathrm{A}, \mathrm{B}$, and $\mathrm{C}$ in a plane $\mathrm{P}$, and a triangle with the points $A^{\prime}, B^{\prime}$, and $C^{\prime}$ in a plane $P^{\prime}$ are connected through the centre of perspectivity $\mathrm{CP}$ and the axis of perspectivity $\mathrm{X}$.

The little Desargues theorem says that "two triangles in space are perspective from a point if and only if they are perspective from a line" (Kodokostas 2014: 1, emphasis in the original). Thus, two triangles with three lines and three points each are only connected through a seventh point, i.e. the centre of perspectivity $\mathrm{CP}$, and a seventh line, i.e. the axis of perspectivity X (Fig. 3). We can apply the Desargues theorem to a basic semiotic sequence and substitute a sign $\mathrm{S}$, an object $\mathrm{O}$, and an interpretant I for $\mathrm{A}, \mathrm{B}$, and $\mathrm{C}$, as well as a sign $S^{\prime}$, an object $O^{\prime}$, and an interpretant $I^{\prime}$ for $A^{\prime}, B^{\prime}$, and $C^{\prime}$. Understanding the Fano plane as a realization of the Desargues theorem meets Peirce's two semiotic axioms, namely (1) that a single semiosis always consists of the triadic relation between a sign, an object and an interpretant; and (2) that "a sign is not a sign unless it translates itself into another sign in which it is more fully developed" (CP 5.594). 
The next question to be answered is concerned with how the basic semiotic sequence forms into a semiotic system, where there is a path from every element of the system to every other element of the system; this is an essential criterion every system has to meet (Backlund 2000: 448). Looking at the Fano plane is again helpful in this respect, because it can be understood as a generating set. ${ }^{8}$ In contrast to the completed Fano plane, the Fano plane generates by relating two points at one time directly with each other without three points being on one line, e.g. as shown in Fig. 2a (there are several possibilities). If we exchange the non-zero ordered triples of binary digits with semiotic units consisting of a triadic relation between $\mathrm{S}, \mathrm{O}$, and I (see Fig. $2 \mathrm{~b}$ ), we can follow the path that the basic socio-cultural semiotic system takes when emerging from the three-dimensional, undirected semiosphere.

However, the semiotic generating set shown in Fig. $2 \mathrm{~b}$ is still in an analogous, parallel state, since the seven semiotic units constituting a triadic relation between $\mathrm{S}, \mathrm{O}$, and I are not yet specified. They have to be brought into a function where each sign is digitized by a binary code. As Terrence Deacon (1997: 71) stresses:

No particular objects are intrinsically icons, indices, or symbols. They are interpreted to be so, depending on what is produced in response. In simple terms, the differences between iconic, indexical, and symbolic relationships derive from regarding things either with respect to their form, their correlations with other things, or their involvement in systems of conventional relationships. [...] These modes of reference aren't mutually exclusive alternatives; though at any one time only one of these modes may be prominent, the same signs can be icons, indices, and symbols depending on the interpretive process. But the relationships between icons, indices, and symbols are not merely a matter of alternative interpretations. They are to some extent internally related to one another.

Thus, the three aspects of semiosis - the aspect of the sign, the aspect of the reference to an object, and the aspect of the interpretant - have to be brought into a sequential order, structured by a code. As is the case in all higher systems such as living systems, information processing in the basic socio-cultural semiotic system must consist of a code that is segregated, linear and digital in contrast to processes that are blended, three-dimensional and analogous. This is in accordance with processing information in an organic cell: "[...] heredity is transmitted by factors that are 'segregated, linear and digital' whereas the compounds of chemistry are

8 In mathematical terms, a generating set is defined as follows: "Let $G$ be a group and let $S$ $\subset G$ be a subset. The subgroup generated by $S$ in $G$ is the smallest subgroup (with respect to inclusion) of $G$ that contains $S$; the subgroup generated by $S$ in $G$ is denoted by $\langle S\rangle G$. The set $S$ generates $G$ if $\langle S\rangle G=G$. A group is finitely generated if it contains a finite subset that generates the group in question" (Löh 2017: 19). 
'blended, three-dimensional and analog"' (Barbieri 2015: 9, with reference to Yockey 2000). Social systems also transform analogous data into digitized information. Luhmann has introduced the concept of structural couplings to explain this transformation:

In the terminology of informatics, we could say that structural couplings digitize analogue relations. Since the environment and the other systems within it always operate simultaneously with the given reference system of observation, we are initially dealing only with analogue (parallel) relations. The participating systems cannot extract any information, for this requires digitization. Structural couplings must therefore first convert analogue into digital relations if they are to influence a system. In relations between the communication system and consciousness systems, this is a function of language, which converts a continuous 'alongside' into a discontinuous succession. (Luhmann 2012 [1997]: 55)

Due to this formal accordance between organic and socio-cultural processes, a look at research on modelling life might be helpful in understanding the composition of the elementary socio-cultural semiotic system and the way in which the elementary socio-cultural semiotic system produces information.

\section{Modelling life}

Biosemiotics is an emerging field in which semiotics is applied to organic processes (see, e.g., Hoffmeyer 2008; Emmeche, Kull 2011). However, semiotics and theoretical systems biology do not seem to be connected to each other yet. In theoretical biology, Robert Rosen, whose "approach is a path towards biosemiotics" (Kull, Emmeche, Hoffmeyer 2011: 10), has modelled the (M,R)-system, where $M$ and $R$ signify metabolism and repair, respectively (Rosen 1991). The diagram looks as follows (Fig. 4):

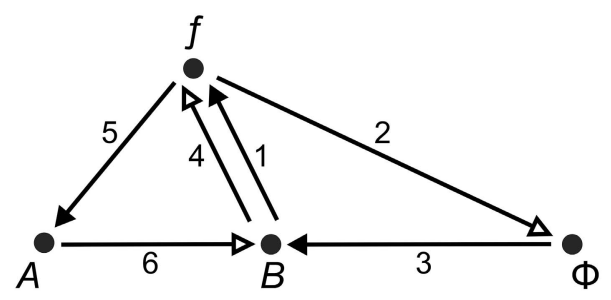

Figure 4. Rosen's diagram 10C.6 depicting the $(M, R)$-system (Rosen 1991: 251). In order to provide a better overview, the lines are numbered according to Cottam, Ranson, Vounckx 2007: 2359 . 
The $(M, R)$-system consists of the following elements and functions: the metabolical processor $f$ uses inputs from set $A$ (where single elements $a$ stem from) to produce outputs of set $B$ (where single elements $b$ stem from). $f$ is caused by the repair (or exchange) processor $\Phi$, which in turn is generated by a replication (or closure) processor from set $B$. The result is a circular system: “[...] every function is indeed entailed by another function in the graph itself. As far as entailment is concerned, the environment is out of the picture completely, except for the initial input $A$ " (Rosen 1991: 251). The relations are:

$f \rightarrow a \rightarrow b \quad$ metabolism (relations 5 and 6 )

$f \rightarrow \phi \rightarrow b \quad$ repair [or exchange] function (relations 2 and 3)

$b \rightarrow f \quad$ replication [or closure] function (relations 1 and 4) [the alternative designations of the functions are from Letelier, Cárdenas, CornishBowden (2011: 105)].

The model involves a number of difficulties, as has been widely discussed (see, e.g., Kineman 2012; Cárdenas et al. 2010; Cottam, Ranson, Vounckx 2007; Goudsmit 2007; Letelier, Marín, Mpodozis 2003), especially regarding the relationship between mechanism (hardware) and organism (software). Although a mechanism in the $(M, R)$-system can "contain" an organism and vice versa, the distinction remains sharply binary, as Cottam, Ranson and Vounckx (2007: 2359) argue:

Abstractly, the recognition in general of a single object implies the existence of not two, but three separate domains: the object, its ecosystemic environment, and their interface: the bifurcating categorization of Nature proposed by Rosen into the complement of mechanism and organism is insufficient. An organism is not the complement of a mechanism: the complement of a mechanism is its ecosystem.

Recent research suggests a complex interplay between digital (i.e. code-driven) processes and analogous processes (i.e. exchange processes between system and its external surroundings) within a cell (Cottam, Ranson, Vounckx 2007: 2357; Hoffmeyer 2008; Giorgi, Bruni, Maggio 2010; Arnellos et al. 2012). ${ }^{9}$ Accordingly, Cottam, Ranson and Vounckx (2007:2360) identify relations 2 and 3 in the $(M, R)$ system (Fig. 4 ) as the ecosystem that complements the mechanism. Therefore, an organism is "the complex interface between mechanism and ecosystem" (Cottam et al. 2007: 2363). The ecosystem is part of the specific environment (Umwelt) represented within the system - in contrast to the surroundings (Umgebung)

9 Regarding the relation between analogous and digital processes, see also Bateson 1987[1972]: 213 and Luhmann 2012[1997]: 55. 
that are amorphic to the system and bear no information for it. ${ }^{10}$ The relation between the system (self-reference) and its internally represented environment (other-reference) is also called niche construction in biology (Laland, Matthews, Feldman 2016). As a result, the diagrammatic solution offered by Cottam, Ranson and Vounckx looks like a schematization of the figure eight, or, projected into a three-dimensional space, like the Möbius strip (Figure 5a).

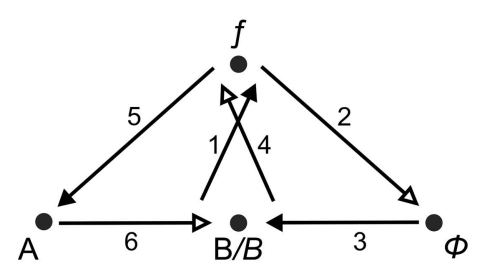

(a)

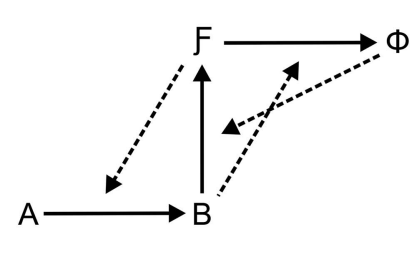

(b)

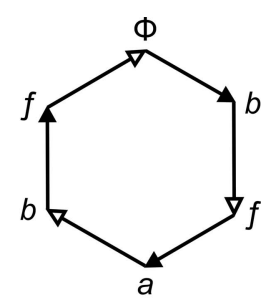

(c)

Figure 5. Variations of Rosen's diagram 10C.6 depicting the $(M, R)$-system: (a) by Cottam, Ranson, Vounckx (2007: 2358), (b) by Goudsmit (2007: 2428), and (c) by Louie (2013: xxix).

The concept of the ecosystem (or niche construction) is an important complement to Rosen's model of the $(M, R)$-system. It corresponds to the insight of systems theory that "a system is the difference between system and environment" (Luhmann 2006: 38). Nevertheless, further modifications of the model of the $(M, R)$-system have to be made.

- First, if the $(M, R)$-system is autopoietic and self-referential (Letelier, Marín, Mpodozis 2003), the functions not only have to be caused by one another, but there must also exist mutual foundations of the relations; as Goudsmit (2007: 2428) argues (see Fig. 5b):

Accordingly, in the diagram [...] a closed loop of efficient causation is represented between the sets Phi, F, and B, each of which is considered to be an efficient cause of a metabolic process that produces one of the others. Thus, a particular set can simultaneously act in two or more different causal 'roles'.

10 The concept of the environment (Umwelt) as belonging to the system was introduced by Jakob von Uexküll. In addition, he distinguished between the system-internal environment (Umwelt) and the system-external surrounding (Umgebung) that is amorphic to the system; see Uexküll (2014[1921]). 
- Second, the processors of the $(M, R)$-system are part of a hierarchical cycle, as argued by Louie (2013: xxix) (Fig. 5c). A hierarchical cycle consists of three levels (Salthe 1985; Queiroz, El-Hani 2006). This is the reason why there have to be three positions of the set $B$.

- Third, a system involves at least two processors, as systems theory has realized (Luhmann 1995: 138). Thus, the metabolical processor $f$ shown in Rosen's diagram (Fig. 4) is only one processor of the set F, as considered in Louie's diagram (Fig. 5c).

Taking all of the mentioned modifications into consideration, the $(M, R)$-system can be modelled as follows (Fig. 6):

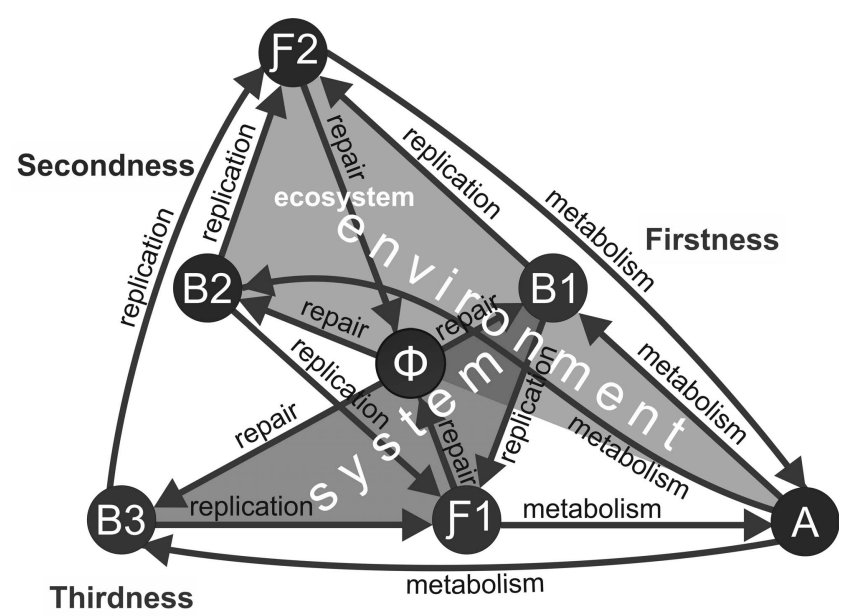

Figure 6. Modified diagram of the $(M, R)$-system considering self-reference, mutual causation and foundation of the functions, multiple closure, and recursivity in a three-level hierarchy. $\mathrm{B}, \mathrm{F}, \Phi$, and $\mathrm{A}$ stand for sets of the respective elements $\mathrm{b}, f, \varphi$, and $\mathrm{a}$. B and $\mathrm{F}$ are depicted in the different causal "roles" 1 and 2, or, in the case of B, 1, 2, and 3 (Goudsmit 2007: 2428).

The diagram shown in Fig. 6 considers (a) the representation of the system's environment inside the system (including the ecosystem or niche construction); (b) mutual foundation of the functions; (c) the system's need for more than one metabolic processor $f$; (d) multiple closure via replication processes; and (e) recursivity in a three-level hierarchy. In formal semiotic terms, the $(M, R)$-system proceeds from Firstness $\left(B_{1} \rightarrow F_{1}\right)$ as "a focal symmetry generating force" (Taborsky 2003: 12) via Secondness $\left(F_{1} \rightarrow \Phi \rightarrow B_{2} \rightarrow F_{2}\right)$ as an "eccentric or chance-driven asymmetry 
generating force" (Taborsky 2003: 12) to Thirdness $\left(F_{2} \rightarrow A \rightarrow B_{3}\right)$ as "the insertion of an irreversible point of attention, a direction that generates a measured asymmetrical closure" (Taborsky 2003: 12). From there, the system mediates its internal processes.

\section{Modelling the elementary socio-cultural semiotic system. Part II}

Now that it has become clear what the structure of segregated, linear and digital processes in a cell looks like, conclusions can be drawn from the insights of theoretical biology for modelling the basic socio-cultural semiotic system. The following structural analogies of an isomorphism type between organic and socio-cultural processes of producing information can be identified:

- The metabolical processor $f$ corresponds to the interpretant I.

- The repair (or exchange) processor $\Phi$ corresponds to certain aspects of the object $\mathrm{O}$, namely to its physical and organic aspects.

- The input set A corresponds to specific mental aspects of the object O, i.e. to those mental aspects of $\mathrm{O}$ that are transformed into the other-referential environment of the mental systems that participate in the semiotic communication process.

- The output set B corresponds to the sign $\mathrm{S}$ as the output of semiosis.

Thus, the semiotic code specifies the seven units of the semiotic generating set (Fig. 2b) according to their causal "role" (Goudsmit 2007: 2428) within the linear, sequential function $\mathrm{S}_{1} \rightarrow \mathrm{I}_{1} \rightarrow \mathrm{O}_{1} \rightarrow \mathrm{S}_{2} \rightarrow \mathrm{I}_{2} \rightarrow \mathrm{O}_{2} \rightarrow \mathrm{S}_{3}$ :

- The first semiotic unit of the triadic relation between $\mathrm{S}, \mathrm{O}$, and I focuses on the sign aspect of semiosis within Firstness.

- The second semiotic unit stresses the aspect of the interpretant of semiosis within Firstness.

- The third semiotic unit accentuates the object aspect of semiosis within Firstness.

- The fourth semiotic unit focuses again on the sign aspect of semiosis, however, now within Secondness.

- The fifth semiotic unit stresses again the aspect of the interpretant in semiosis, however, now within Secondness.

- The sixth semiotic unit accentuates again the object aspect of semiosis, however, now within Secondness.

- The seventh semiotic unit focuses a third time on the sign aspect of semiosis, however, now within Thirdness. 
All in all, the elementary socio-cultural semiotic system based on the semiotic code can be modelled as follows (Fig. 7):

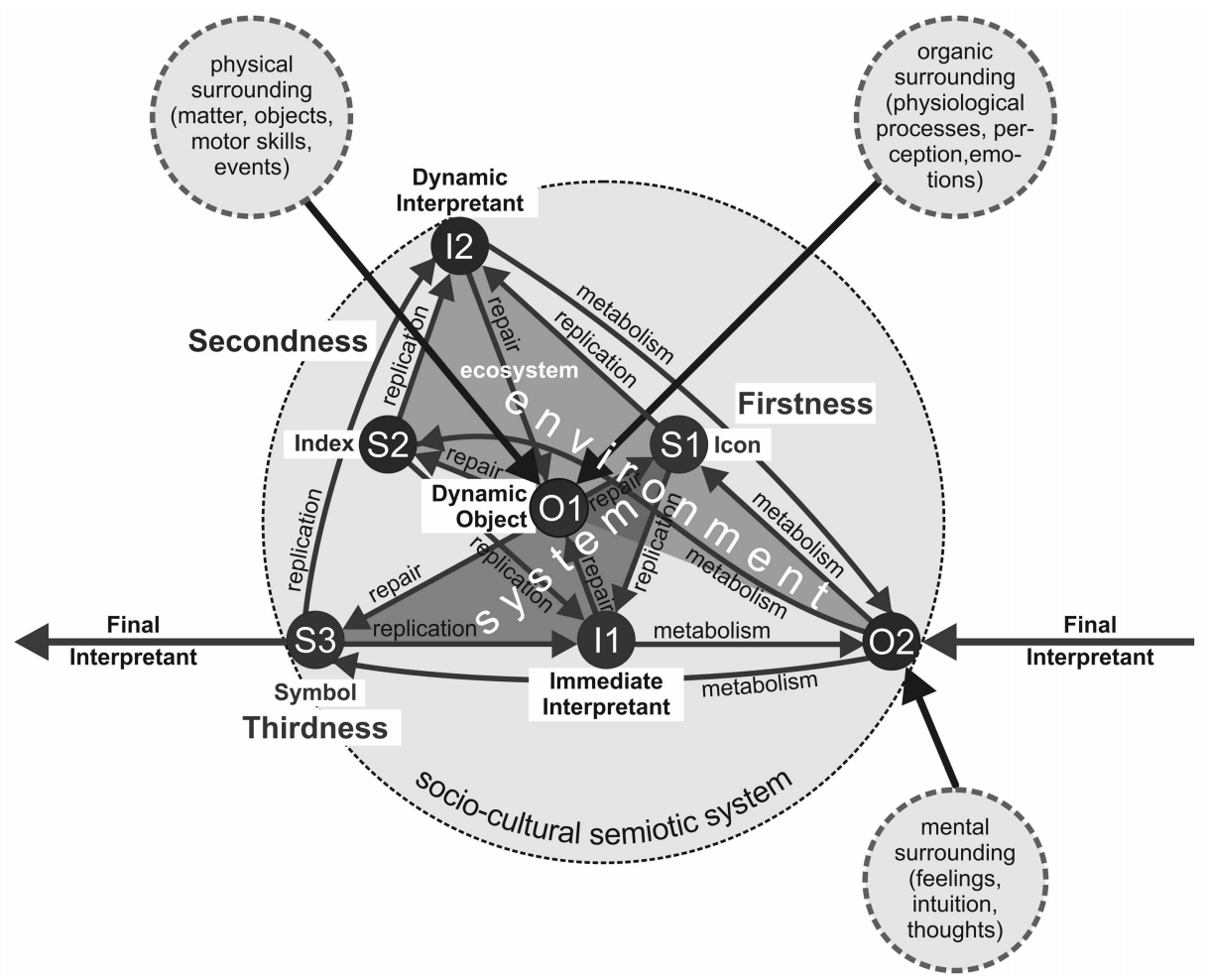

Figure 7. The basic socio-cultural semiotic system with (a) the internal distinction between system and its specific environment, (b) its mental, organic, and physical surroundings; and (c) the functions of replication, repair, and metabolism. S, I, and O stand for sets of signs, objects, and interpretants, respectively. They are depicted in the different causal "roles" 1 and 2, or, in the case of S, 1, 2, and 3 (Goudsmit 2007: 2428).

In the elementary socio-cultural semiotic system, the three signs $S_{1}, S_{2}$, and $S_{3}$ have the following semiotic value with respect to objects:

- $\mathrm{S}_{1}$ functions as an icon that stresses the aspect of the sign itself in relation to an object within Firstness (self-reference);

- $\mathrm{S}_{2}$ functions as an index that refers to an object within Secondness (otherreference);

- $\mathrm{S}_{3}$ functions as a symbol that mediates the relation between the interpretant and the object within Thirdness (system-reference). 
The immediate interpretant $I_{1}$ provides potential concepts, the dynamic interpretant $I_{2}$ supplies actual concepts, and the final interpretant is the context to which the elementary socio-cultural semiotic system connects, or the function in which the system is embedded. ${ }^{11} \mathrm{O}_{1}$ accentuates the dynamic aspect of the system-internally represented environment and refers to physical and organic states and processes, while $\mathrm{O}_{2}$ stresses the immediate aspect of the system-internally represented environment and refers to mental states and processes. ${ }^{12}$ The semiotic code replicates via the relation $\mathrm{S}_{1} \rightarrow \mathrm{I}_{1}$, followed by a repair (or, exchange) process $\mathrm{I}_{1} \rightarrow \mathrm{O}_{1} \rightarrow \mathrm{S}_{2}$, in which the socio-cultural semiotic system is sensitive to its external physical and organic surroundings (Umgebung). The socio-cultural semiotic system then exchanges data with its external surroundings by collating its code with it and thus constitutes a system-internally represented environment (Umwelt) $\left(\mathrm{S}_{2} \rightarrow \mathrm{I}_{2}\right)$. The relations $\mathrm{S}_{2} \rightarrow \mathrm{I}_{2} \rightarrow \mathrm{O}_{1} \rightarrow \mathrm{S}_{1}$ and $\mathrm{S}_{1} \rightarrow \mathrm{I}_{2} \rightarrow \mathrm{O}_{1} \rightarrow \mathrm{S}_{2}$ constitute the ecosystem. In analogy with cell processes, through the relations $\mathrm{I}_{2} \rightarrow \mathrm{O}_{2}$ $\rightarrow \mathrm{S}_{3}, \mathrm{I}_{1} \rightarrow \mathrm{O}_{2} \rightarrow \mathrm{S}_{1}$, and $\mathrm{I}_{2} \rightarrow \mathrm{O}_{2} \rightarrow \mathrm{S}_{2}$ 'semiotic metabolism' takes place, in which the socio-cultural semiotic system - controlled by $\mathrm{I}_{2}$ and $\mathrm{I}_{1}$, respectively - selects data from its mental surrounding at the position of $\mathrm{O}_{2}$ and transforms it via the system-internal environment into system-relevant information.

The identified isomorphism between the $(M, R)$-system and the elementary socio-cultural semiotic system prompts questions regarding the succession of semiosis. It is well known that Peirce conceptualized the semiotic sequence as follows: a sign $\mathrm{S}$ refers to an object $\mathrm{O}$, and this relation triggers an interpretant I that in turn might become a sign. However, it is to be noted that semiosis has to be divided into two temporally separate phases, namely a sign-establishment phase where a single three-dimensional link between $\mathrm{S}, \mathrm{O}$, and I is formed, and a sign-utilization phase where the established link is used for inferring significance within a semiotic sequence (Kilstrup 2015). While the sequence in the signestablishment phase is $\mathrm{S} \rightarrow \mathrm{O} \rightarrow \mathrm{I} \rightarrow \mathrm{S}$, it is $\mathrm{S} \rightarrow \mathrm{I} \rightarrow \mathrm{O} \rightarrow \mathrm{S}$ in the sign-utilisation phase in communication - as, analogously, is the case with $\mathrm{B} \rightarrow \mathrm{F}, \mathrm{F} \rightarrow \Phi \rightarrow \mathrm{B}$ and $\mathrm{F} \rightarrow \mathrm{A} \rightarrow \mathrm{B}$, respectively, in the $(M, R)$-system. Moreover, the direction that the model of the elementary socio-cultural semiotic system takes follows the distinction

11 " $[\mathrm{T}]$ he immediate interpretant is a potentiality in which consists the sign's interpretability; the dynamic interpretant is any interpretant actually formed (from zero to many); and the final interpretant is another potentiality, the ideal interpretant of that sign for the interpretative purpose" (Short 2007: 178).

12 "[...] we have to distinguish the Immediate Object, which is the Object as the Sign itself represents it, and whose Being is thus dependent upon the Representation of it in the Sign, from the Dynamical Object, which is the Reality which by some means contrives to determine the Sign to its Representation" (CP 4.536). 
between sense (Sinn) and reference (Bedeutung) as introduced by Gottlob Frege (1960[1892]). While the relation $\mathrm{S}_{1} \rightarrow \mathrm{I}_{1} \rightarrow \mathrm{O}_{1} \rightarrow \mathrm{S}_{1}$ constitutes iconic sense (or, in terms of systems theory, self-reference), the sequence $\mathrm{S}_{2} \rightarrow \mathrm{I}_{2} \rightarrow \mathrm{O}_{1} \rightarrow \mathrm{S}_{2}$ produces indexical reference (or, in terms of systems theory, other-reference).

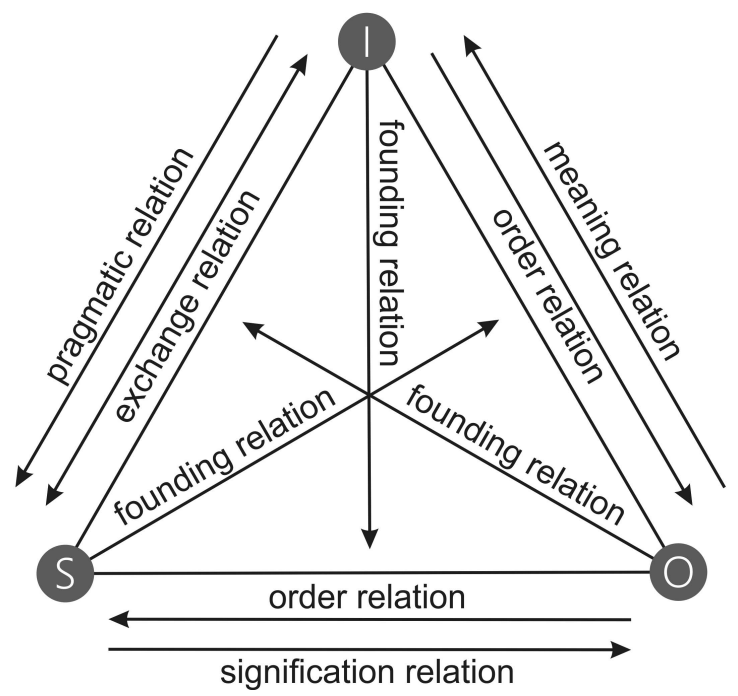

Figure 8. The nine relations between the sign S, the object $\mathrm{O}$, and the interpretant $\mathrm{I}$.

The relationship between sign establishment und sign utilization needs further elaboration. In principle, the triadic unity between $\mathrm{S}, \mathrm{O}$, and I consists of nine relations (Fig. 8), as shown by Ditterich (1990: 91-103) and Toth (2008: 28-36), with reference to polycontextural logics developed by Gotthard Günther (1976):

- of a signification relation between $\mathrm{S}$ and $\mathrm{O}$,

- a meaning relation between $\mathrm{O}$ and $\mathrm{I}$,

- and a pragmatic relation between I and S (Walther 1979[1974]: 113-116);

- of an order relation between I and O

- as well as between $\mathrm{O}$ and $\mathrm{S}$,

- whereas $S$ and I are connected through an exchange relation;

- and of three founding relations: $\mathrm{S}$ founds the relation between I and $\mathrm{O}$, I founds the relation between $\mathrm{S}$ and $\mathrm{O}$, and $\mathrm{O}$ founds the relation between $\mathrm{S}$ and $\mathrm{I}$.

Thus, a "bizarre hierarchy" (Kercel 2002: 135) between the seven semiotic units constituting a triadic relation of $\mathrm{S}, \mathrm{O}$, and I exists inside the elementary sociocultural semiotic system in its dynamic state. However, systems must be studied 
when they are in a synchronous - i.e. in a segregated, linear and digital - state, "because it is only then that they gain a quasi-determinacy sufficient to characterize them" (Salthe 1993: 232). In a synchronous state of the elementary sociocultural semiotic system, the seven semiotic units consisting of a triadic relation between $\mathrm{S}, \mathrm{O}$, and I qualify as stressing one of the three semiotic components during the sequence $\mathrm{S}_{1} \rightarrow \mathrm{I}_{1} \rightarrow \mathrm{O}_{1} \rightarrow \mathrm{S}_{2} \rightarrow \mathrm{I}_{2} \rightarrow \mathrm{O}_{2} \rightarrow \mathrm{S}_{3}$ in analogy to the modified diagram of the (M,R)-system (Fig. 7).

Furthermore, it has to be considered that a socio-cultural semiotic system like every system - proceeds as the distinction between system and environment (Umwelt) (Luhmann 2006: 38). Since the socio-cultural semiotic system does not have direct access to the amorphic surroundings (Umgebung) outside the system, the environment that is relevant for the system is exclusively represented systeminternally. The self-referential system consists of the relations between $S_{1}, I_{1}$, and $S_{3}$, while the system-internally represented other-referential environment is constituted via the relations between $\mathrm{S}_{2}, \mathrm{I}_{2}$, and $\mathrm{O}_{2}$. Like organisms, socio-cultural semiotic systems do not passively adapt to conditions in their surroundings, but actively construct and modify observed (i.e. distinguished) conditions outside the system that may influence other sources of selection (regarding organisms, see Lewontin 2000).

In accordance with the distinction between the system-external surrounding (Umgebung) and the system-internal environment (Umwelt), semiotic representation at the position of the sets $\mathrm{O}_{1}$ and $\mathrm{O}_{2}$ does not mean a direct reference to the external surrounding, but signifies system-internal observation of the environment. The socio-cultural semiotic system - controlled by the two interpretants $\mathrm{I}_{1}$ and $\mathrm{I}_{2}$ - selects data from its external surroundings at the position of the sets $\mathrm{O}_{1}$ and $\mathrm{O}_{2}$ as the two input locations of the socio-cultural semiotic system. While other-reference to $\mathrm{O}_{1}$ as part of the ecosystem is sensitive to the system's physical and organic environment and exchanges data between the system and its environment, other-reference to $\mathrm{O}_{2}$ is strictly code-driven; this means that the system at the position of $\mathrm{O}_{2}$ selects only the kind of data of its mental environment that is relevant for processing information in the socio-cultural semiotic system. In analogy to cell metabolism, the semiotic functions $\mathrm{I}_{1} \rightarrow \mathrm{O}_{2} \rightarrow \mathrm{S}_{1}$ and $\mathrm{I}_{2} \rightarrow \mathrm{O}_{2} \rightarrow$ $\mathrm{S}_{3}$ transform relevant data from the mental external surroundings and process these within the system ${ }^{13}$, while in the functions $\mathrm{S}_{1} \rightarrow \mathrm{I}_{1}, \mathrm{~S}_{1} \rightarrow \mathrm{I}_{2}, \mathrm{~S}_{3} \rightarrow \mathrm{I}_{1}$, and $\mathrm{S}_{3} \rightarrow$

13 Regarding the purpose of immediate objects in communication, see Bellucci 2015: 411; however, he writes within the frame of the outdated communication model of sender (or utterer) and receiver (or interpreter): "Immediate objects account for the intersubjectivity of reference. A sign functions as such if it identifies an object that is common to the utterer's and the interpreter's experiences." 
$\mathrm{I}_{2}$ the semiotic code is replicated. Within the functions $\mathrm{I}_{2} \rightarrow \mathrm{O}_{1} \rightarrow \mathrm{S}_{2}$ and $\mathrm{I}_{2} \rightarrow \mathrm{O}_{1}$

$\rightarrow S_{1}$ the socio-cultural semiotic system exchanges information with its external environment in an analogous way (in contrast to the metabolism functions on the basis of code replication). After having selected relevant data controlled by one of the two interpretants in each case, the socio-cultural semiotic system transforms these into specific meaning with the sign components of the sets $S_{3}, S_{2}$, and $S_{1}$ as the intrasystem output.

\section{Modelling the basic religious system}

Against the background of the general considerations on semiotics that is informed by geometry, theoretical biology, and systems theory, the question of how religious semiosis proceeds finally is to be considered. Semiotics has been applied to the study of religion for some time now (see, e.g., Yelle 2013, 2017; Leone 2010, 2014a; Kreinath 2006; Murphy 2003). However, semiotic research on religion might benefit from social systems theory in order to understand how religious semiosis proceeds systemically. Social systems theory treats religion not only as "an eminently social thing" (Durkheim 1995[1912]: 9), but as a special subsystem of the functionally differentiated society that proceeds as communication in different domains (Luhmann 2012[1997], 2013). In contrast to acts of general transcendence in sign-based communication (Schütz, Luckmann 2003[1979]: 598-633), religion is a kind of semiosis that signifies everything on the basis of the binary distinction between immanence and transcendence, while ultimately coping with undetermined contingency (Luhmann 2013). That is why religious transcendence is a second order-transcendence, i.e. “Transcendence' (with a capital ' $T$ ') or 'Absolute Transcendence"' (Dalferth 2012: 155). The religious system exists only through the combination of the function of ultimately coping with undetermined contingency and of the code 'immanent/transcendent'. It proceeds as a societal function and is at the same time internally based on the code 'immanent/transcendent'. Neither the societal function nor the religious code alone would be sufficient to conceptualize religion and to identify it empirically. Religion specifies the general semiotic code as the code 'immanent/transcendent' in order to proceed systemically, to distinguish itself from other societal subsystems such as politics, law, economics, science, and arts, etc., in order to fulfil the societal function of ultimately coping with otherwise undetermined contingency. With its code 'immanent/transcendent', religion interprets "the world as two-layered, so that some objects and events of mundane experience are like signs expressing meanings that concern a hidden and more fundamental level 
of existence" (Deacon, Cashman 2009: 490). In accordance with the assumption that the religious code in a nutshell comprises all that is necessary for religious communication (as is the case with the genetic code in organic evolution), the binary distinction together with its mediating unity must be found in the religious code. Taking into consideration the distinction between self-reference (system) and other-reference (environment) as well as the code distinction between immanence and transcendence, including self-referential iconic unity of immanence and transcendence at level I of the hierarchical cycle, their other-referential indexical relation at level II of the hierarchical cycle, and the self-referential symbolic mediation of the unity and relation of immanence and transcendence at level III of the hierarchical cycle (Salthe 1985), the basic religious system can be modelled as follows (Fig. 9):

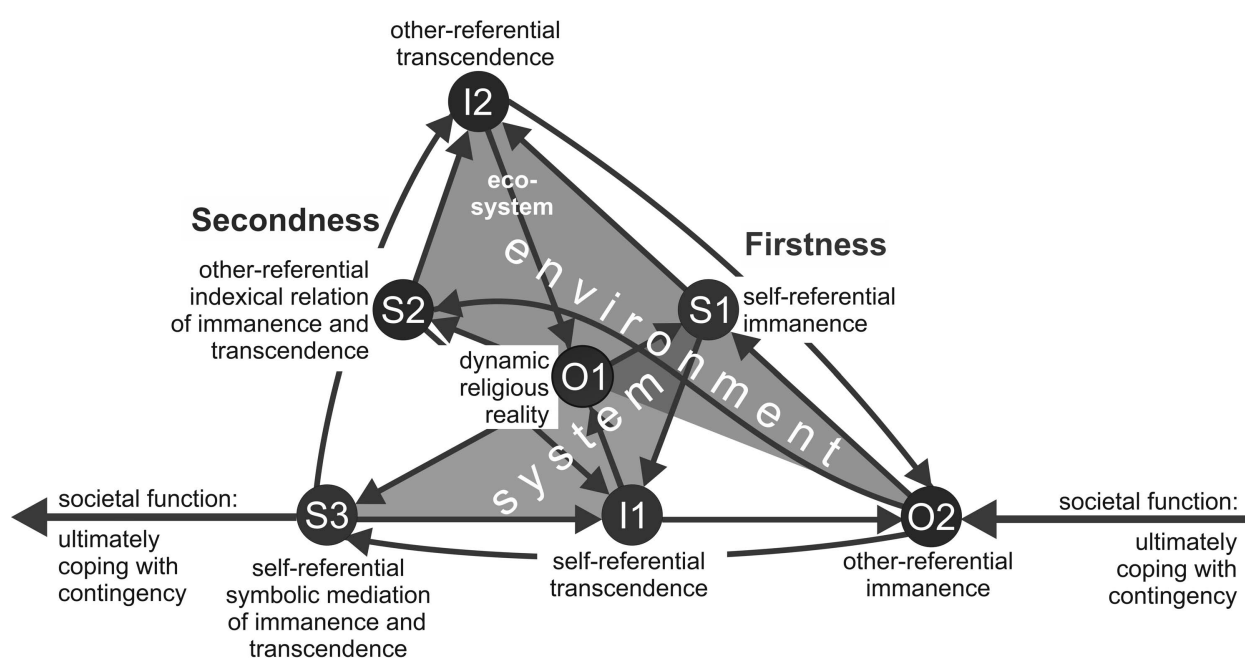

Thirdness

Figure 9. The basic religious system with the internal distinction between system and its specific environment and based on the code immanent/transcendent. S, I, and O stand for sets of signs, objects, and interpretants, respectively. They are depicted in the different causal 'roles' 1 and 2, or, in the case of S, 1, 2, and 3 (Goudsmit 2007: 2428).

Religious semiosis - like every semiosis - always starts by connecting to a previous sign of set $\mathrm{S}_{1}$ (Leone 2014b: S50). As the religious system is in the process of being formed, $S_{1}$ has the code value of immanence. However, it only becomes an immanent component of religious semiosis through the closure in the direction of self-referential transcendence at the position of $I_{1}$ as the first processor, 
since designating something as immanent only makes sense in relation to transcendence. The self-referential closure based on the code immanent/transcendent' is the first system-constitutive distinction. If, as a result, the sign system is determined to be religious, the opening to the next state of the system must also be based on the religious code. $\mathrm{I}_{1}$ determines $\mathrm{O}_{1}$ as the dynamic religious reality, which leads to $S_{2}$ with the code value of other-referential indexical relation of immanence and transcendence. This is the first step of the emergence of religious information in the sense of "a difference which makes a difference", as Gregory Bateson (1987[1972]: 276, 321 et passim) defines information. O $_{1}$, i.e. the religious reality, is a dynamic and fuzzy object, because it is the object of both the iconic sign $S_{1}$ and the indexical sign $S_{2} . S_{2}$ has the code value of the other-referential indexical relation of immanence and transcendence, because it triggers $I_{2}$ with the code value of other-referential transcendence under immanent conditions. Thus, it is open to the system's external environment as part of the repair (or exchange) process $\mathrm{I}_{1} \rightarrow \mathrm{O}_{1} \rightarrow \mathrm{S}_{2}$ of the religious system's ecosystem or niche construction, respectively. This process is analogous to genotypes evolving sensitivities to the environmental conditions that they construct (Wolinsky, Libby 2016). ${ }^{14}$ On the other hand, $\mathrm{S}_{2}$ stands in relation with the immediate interpretant $\mathrm{I}_{1}$. On the basis of the repair (or exchange) function, "religious metabolism", i.e. the transformation of environmental data into specific religious information, takes place in relation $\mathrm{I}_{2} \rightarrow \mathrm{O}_{2}$ $\rightarrow S_{3}$, i.e. from other-referential transcendence via other-referential immanence to the self-referential symbolic mediation of immanence and transcendence. The religious system selects relevant data from its mental analogous surroundings at the position of $\mathrm{O}_{2}$ and transforms it into system-specific information. This selection is controlled by $\mathrm{I}_{2}$ and results in $\mathrm{S}_{3}$.

Empirical data taken from the history of religion exemplifies the validity of the model. The empirical data stems from the book Das fliessende Licht der Gottheit (The Flowing Light of the Godhead) (FLG). Its authorship is attributed to Mechthild of Magdeburg ${ }^{15}$, who is known for reporting religious out-of-body experiences (OBE). The book is an assortment of mystical visions, letters, reflections, prayers, and advice. In section II.18 the text describes the way of in which the soul can "touch" (berưret) the "freedom of God" (gottes vrîheit) and refers to sense perception.

14 The concept of niche construction in this sense has already been applied to religious evolution (Bulbulia 2008).

15 Mechthild of Magdeburg ( ${ }^{*}$ around $1207 ; \dagger 1282$ ) was a Christian mystic, born in a noble Saxon family. It is reported that she had her first vision of the Holy Spirit at the age of twelve. In 1230 Mechthild of Magdeburg left her home and became a Beguine probably at Magdeburg, Saxonia. There she seemed to have exercised a position of authority in a Beguine community. The Beguines are a Christian lay religious order. 
Table 1. A passage from the book The Flowing Light of the Godhead.

\begin{tabular}{|l|l|}
\hline $\begin{array}{l}\text { Middle High German version } \\
\text { von Magdeburg 1869: 37) }\end{array}$ & $\begin{array}{l}\text { English translation (Mechthild von } \\
\text { Magdeburg 2003: 43) }\end{array}$ \\
\hline $\begin{array}{l}\text { [...] min irdensch sinken kunt von diner } \\
\text { einunge mines lichamen. Je grósser lósunge } \\
\text { du mir gist, je langer ich in dir můs sweben. }\end{array}$ & $\begin{array}{l}{[\ldots] \text { my sinking back to earth is because }} \\
\text { of Your union with my body. The more } \\
\text { You free me, the longer I may hover in } \\
\text { You. }\end{array}$ \\
\hline
\end{tabular}

Against the backdrop of the semiotic considerations made above, the quoted passage (Table 1) can be brought into the following semiotic structure, observing it in a synchronous state (Fig. 10):

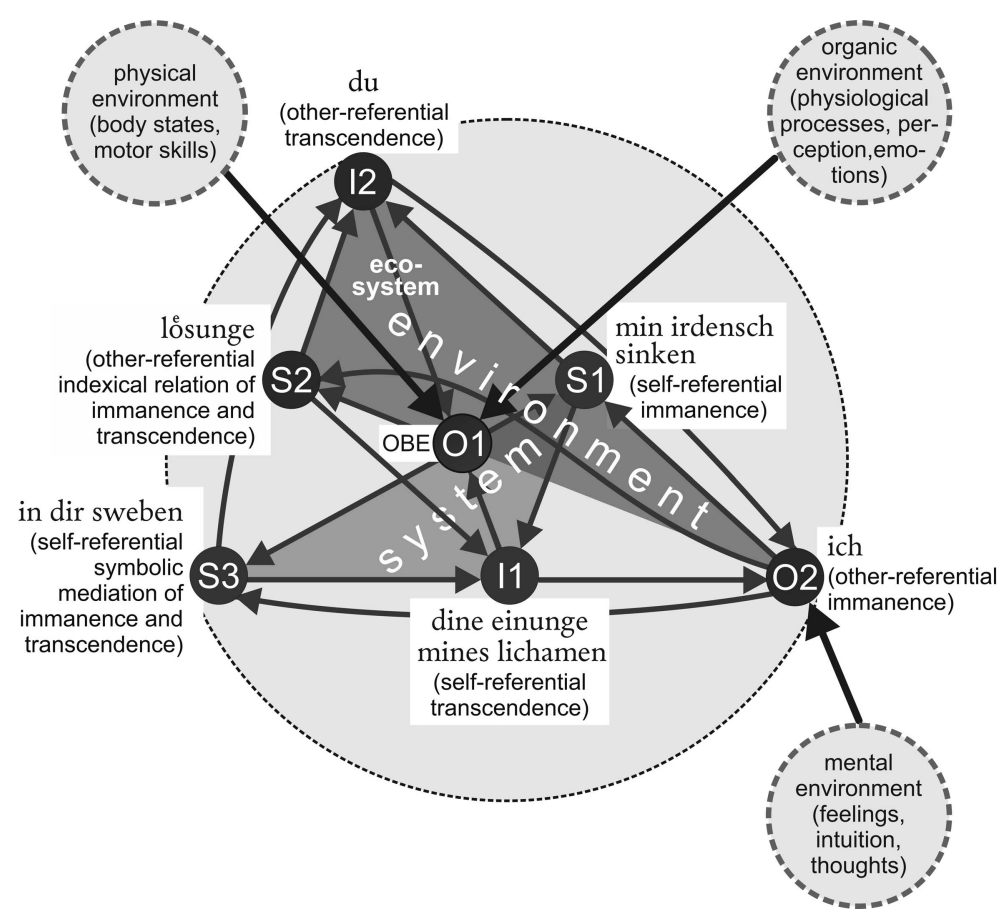

Figure 10. Mechthild of Magdeburg's account of an out-of-body experience (OBE) as a socio-cultural semiotic system in a synchronous state.

16 The original written in Middle Low German is lost. 
According to the model of the basic religious system (Fig. 9), 'min irdensch sinken' ('my earthly sinking') is situated in the position of self-referential immanence $\left(\mathrm{S}_{1}\right)$, because it is a communicative signification of a feeling that reflects an immediate bodily emotion. ${ }^{17}$ 'Dine einunge mines lichamen' ('Your union with my body') is placed in the position of self-referential transcendence $\left(\mathrm{I}_{1}\right)$, because the phrase refers to God as a transcendent entity. The concept 'einunge' ('union'; the 'unio mystica') semantically reflects the iconic unity of $\mathrm{S}_{1}, \mathrm{I}_{1}$, and $\mathrm{O}_{1}$. 'losunge' (physical meaning: 'separation'; religious meaning: 'redemption') stands in the position of the indexical relation of immanence and transcendence, because it refers to the physical process of separation and likewise to the religious concept of redemption. ' $D u$ ' ('You' [= God]) is placed in the position of other-referential transcendence, because it refers to an actual capacity of God ('Je grosser losunge du mir gist' ['the more You grant me redemption']). 'Ich' (I [= the lyric subject]) is situated in the position of other-referential immanence, because the lyric subject stands for mental processes of readers of the text. The lyric subject is a "cover", into which the reader might "slip" easily (Linden 2011: 379) and thus, maybe by reading the text out loud, transform from a spectator into a participant (Nemes 2012: 47). 'Ich in dir mưs sweben' ('I may hover in You' [= God]) stands in the position of the self-referential symbolic mediation of immanence and transcendence, because the phrase refers to hovering as a physical state and likewise as a religious experience. 'Hovering' semantically reflects the semiotic task of the symbol $S_{3}$, namely to mediate between the system (self-similarity) and its internally represented environment (relational representation). It is to be noted that there is no direct connection between $\mathrm{O}_{1}$ as the physical and organic environment of the sociocultural semiotic system, i.e. the body state, physiological processes, perceptions, and emotions of the author and the lyric subject, i.e. the reader, respectively, and $\mathrm{O}_{2}$ as the environment consisting of the author's and the lyric subject's, i.e. the reader's, mental processes with feelings, intuition, and thoughts. Both kinds of environment represented within the system are mediated through communicatively activated semiosis.

The text FLG is shaped by various semantic fields that are used for building metaphors. The metaphors function as the "metabolism" by which the religious system - controlled by $\mathrm{I}_{2}$ and $\mathrm{I}_{1}$, respectively - selects data from its surroundings

17 The distinction between emotions and feelings is adopted from Damasio and Carvalho (2013: 145): feelings are "[ $t]$ he mental experiences that accompany body states. Action programmes (drives and emotions) can elicit feelings. Experiences related to exteroceptive senses (vision, hearing, touch, taste and smell) commonly cause emotions and ensuing feelings but in general are not felt in and of themselves. This definition also excludes the use of 'feeling' in the sense of 'thinking' or 'intuiting.' In the iconic state, feelings are identified with emotions. 
in the positions of $\mathrm{O}_{1}$ and $\mathrm{O}_{2}$ and transforms these into religious information. ${ }^{18}$ Gravity is one of the used metaphors. ${ }^{19}$ From the perspective of religious sense making, 'up' is the 'positive' (transcendent) value, while 'down' is the 'negative' (immanent) value. In religious communication, both directions are religiously valued; e.g., hell is, although not necessarily, often considered to be 'down'. Thus, religion as a special coordination system of giving meaning to physical space connects to "normal", i.e., non-religious, meaning such as attributions of social status like "HIGH STATUS IS UP" or political attribution like "power is UP" (Lakoff, Johnson 1980: 16) and transforms it into religious meaning. 'Min irdensch sinken' ('my earthly sinking') goes 'down', and 'losunge' ('redemption' or 'release') from the body goes 'up'. Both directions are mediated by 'sweben' ('hovering') in the case of the text FLG.

Eroticism is another semantic field for building metaphors in the text FLG. However, the mystical unification with God bears analogies with sexual intercourse among human beings, but the two are not identical. Thus, the example of the quoted passage shows that the repair (or exchange) function of the sociocultural semiotic system (Fig. 7) consists of metaphors that use semantics of source domains (in this case: gravity and eroticism) to generate religious sense as the target domain. In other words: religious information processes via "conceptual blending" (Fauconnier, Turner 2002). The transcendent that is unknown and absent in principle is made known and present with immanent means. The metabolic function of the semiotic communication system selects relevant data from mental processes of the readers and uses these for performing the semiotic process. In turn, religious sense processed in the semiotic communication system can be adopted by mental systems through reading or recitation, which has been a common practice in monasteries in the times of Mechthild of Magdeburg (Nemes 2012).

\section{Conclusion: Isomorphism between organic and religious processes}

On the basis of semiotics as a formal tertium comparationis, comparing the modified $(M, R)$-system with the religious system makes the following points clear:

\footnotetext{
18 Psychological and physiological research on out-of-body experiences (OBE) focuses on the organic correlates of communicated OBE, but cannot explain them as religious experience; see, e.g., Braithwaite et al. 2013; Wilkins, Girard, Cheyne 2011; Blanke, Dieguez 2009.

19 Since gravity is referred to metaphorically, no motor skills have to be involved directly, but are referenced semiotically; otherwise, a physical separation from the body would violate the physical law of gravity.
} 
- The socio-cultural semiotic system in general and the $(M, R)$-system as well as the religious system in particular create an "image" of themselves and their environment within the system. This is achieved by observing the first (lower) and second (middle) levels through the third (higher) level of the hierarchical cycle (Salthe 1985).

- The second level of all of the three systems is characterized by the systeminternal interplay between the semiotic code and environmental influences. The second level equals Salthe's conception of the "focal level", which is positioned between the first and the third levels (Salthe 1985: 125; Queiroz, El-Hani 2006). Due to the interplay between the semiotic code and environmental influences at the second level, "an entity can be both $a$ and not- $a$ because it is in the process of changing away from being $a$. A system of this kind would be indeterminate because it is in flux" (Salthe 1993: 232). However, as already noted, systems must be studied when they are in a synchronous - i.e. in a segregated, linear and digital - state, "because it is only then that they gain a quasi-determinacy sufficient to characterize them" (Salthe 1993: 232).

Since every scientific model is to a certain extent based on metaphors (Black 1962; Kuhn 1993; Brown 2003), the models of the elementary socio-cultural semiotic system, of the modified $(M, R)$-system, and of the basic religious system outlined above are based on analogies. Drawing formal analogies by means of semiotics between cell processes and processes of religious sense making reveals an isomorphism between the two. The differentiation of evolutionary spheres concerns respective substrates, whereas the substrate-neutral semiotic structure as a tertium comparationis is isomorphic. This insight corresponds to Louie's characterization of relational biology, namely to "throw away the matter and keep the underlying organization" (Louie 2006: 36, emphasis in the original). Due to the identified isomorphism, it is possible to understand how the religious system selects data from its external surrounding and transforms it into system-specific information via the internally represented environment. On the basis of the finding that semiosis bridges the boundaries between the different evolutionary spheres, further research can be conducted on the question of how religious processes as part of societal communication on the one hand and mental, organic, and physical processes on the other hand interact semiotically. With the help of semiotics, respective research might point to the direction of "the unity of knowledge" (Wilson 1999[1998]) across the natural and social sciences as well as cultural studies in order to better understand religion in the context of general evolution. ${ }^{20}$

20 This work was supported by the German Research Foundation as part of a Reinhart Koselleck Project on a theory and empiricism of religious evolution (Grant KR 2325/13-1). 


\section{References}

Arnellos, Argyris; Bruni, Luis E.; El-Hani, Charbel N.; Collier, John 2012. Anticipatory functions, digital-analog forms and biosemiotics: integrating the tools to model information and normativity in autonomous biological agents. Biosemiotics 5(3): 331-367. https://doi.org/10.1007/s12304-012-9146-4

Backlund, Alexander 2000. The definition of system. Kybernetes 29(4): 444-451. https:// doi.org/10.1108/03684920010322055

Barbieri, Marcello 2007. Is the cell a semiotic system? In: Barbieri, Marcello (ed.), Introduction to Biosemiotics: The New Biological Synthesis. Dordrecht: Springer, 179-207. https://doi.org/10.1007/1-4020-4814-9_8

Barbieri, Marcello 2015. Code Biology: A New Science of Life. Cham Switzerland: Springer.

Bateson, Gregory (ed.) 1987[1972]. Steps to an Ecology of Mind: Collected Essays in Anthropology, Psychiatry, Evolution, and Epistemology. Northvale, London: Jason Aronson Inc.

Bellucci, Francesco 2015. Exploring Peirce's speculative grammar: The immediate object of a sign. Sign Systems Studies 43(4): 399-418. https://doi.org/10.12697/SSS.2015.43.4.02

Black, Max (ed.) 1962. Models and Metaphors: Studies in Language and Philosophy. Ithaca: Cornell University Press. https://doi.org/10.7591/9781501741326

Blanke, Olaf; Dieguez, Sebastian 2009. Leaving body and life behind: Out-of-body and near-death experience. In: Laureys, Steven; Tononi, Giulio (eds.), The Neurology of Consciousness: Cognitive Neuroscience and Neuropathology. Amsterdam, London: Academic Press Fribourg, 303-325. https://doi.org/10.1016/B978-0-12-374168-4. 00023-X

Braithwaite, Jason J.; Broglia, Emma; Bagshaw, Andrew P.; Wilkins, Arnold J. 2013. Evidence for elevated cortical hyperexcitability and its association with out-of-body experiences in the non-clinical population: New findings from a pattern-glare task. Cortex 49(3): 793-805. https://doi.org/10.1016/j.cortex.2011.11.013

Brown, Theodore L. 2003. Making Truth: Metaphor in Science. Urbana: University of Illinois Press.

Bulbulia, Joseph A. 2008. Meme infection or religious niche construction? An adaptationist alternative to the cultural maladaptationist hypothesis. Method \& Theory in the Study of Religion 20(1): 67-107. https://doi.org/10.1163/157006808X260241

Bulbulia, Joseph A.; Geertz, Armin W.; Atkinson, Quentin D.; Cohen, Emma; Evan, Nicholas; Francois, Pieter; Gintis, Herbert; Gray, Russell D.; Henrich, Joseph; Jordon, Fiona M.; Norenzayan, Ara; Richerson, Peter J.; Slingerland, Edward G.; Turchin, Peter; Whitehouse, Harvey; Widlok, Thomas; Wilson, David S. 2013. The cultural evolution of religion. In: Richerson, Peter J.; Christiansen, Morten H. (eds.), Cultural Evolution: Society, Technology, Language, and Religion. (Strungmann Forum Reports.) Cambridge: MIT Press, 381-404. https://doi.org/10.7551/mitpress/9780262019750.003.0020

Burgess, John P. 2015. Rigor and Structure. Oxford: Oxford University Press. https://doi. org/10.1093/acprof:oso/9780198722229.001.0001

Cárdenas, María L.; Letelier, Juan-Carlos; Gutierrez, Claudio; Cornish-Bowden, Athel; Soto-Andrade, Jorge 2010. Closure to efficient causation, computability and artificial life. Journal of Theoretical Biology 263(1): 79-92. https://doi.org/10.1016/j.jtbi. 2009.11.010 
Cobley, Paul 2013. Semiotic models of communication. In: Cobley, Paul; Schulz, Peter J. (eds.), Theories and Models of Communication. (Handbooks of Communication Science.) Berlin, New York: De Gruyter Mouton, 224-240.

Cottam, Ron; Ranson, Willy; Vounckx, Roger 2007. Re-mapping Robert Rosen's (m,r)systems. Chemistry \& Biodiversity 4(10): 2352-2368. https://doi.org/10.1002/cbdv. 200790192

$\mathrm{CP}=$ Peirce 1994 .

Dalferth, Ingolf U. 2012. The idea of transcendence. In: Bellah, Robert N.; Joas, Hans (eds.), The Axial Age and Its Consequences. Cambridge, London: Belknap Press of Harvard University Press, 146-188.

Damasio, Antonio R.; Carvalho, Gil B. 2013. The nature of feelings: Evolutionary and neurobiological origins. Nature Reviews Neuroscience 14(2): 143. https://doi.org/10. 1038/nrn3403

Deacon, Terrence W. 1997. The Symbolic Species: The Co-Evolution of Language and the Brain. New York, London: W. W. Norton \& Co.

Deacon, Terrence W.; Cashman, Tyrone 2009. The role of symbolic capacity in the origins of religion. Journal of Religion, Nature \& Culture 3(4): 490-517. https://doi. org/10.1558/jsrnc.v3i4.490

Deledalle, Gérard (ed.) 2000. Charles S. Peirce's Philosophy of Signs: Essays in Comparative Semiotics. Bloomington: Indiana University Press.

Dennett, Daniel C. 2006. Breaking the Spell: Religion as a Natural Phenomenon. New York: Viking.

Ditterich, Joseph 1990. Selbstreferentielle Modellierungen: Biologie - Kybernetik. Klagenfurt: IFF-Arbeitsbereich 'Technik- und Wissenschaftsforschung'.

Durkheim, Émile (ed.) 1995[1912]. The Elementary Forms of Religious Life. (Fields, Karen E., trans., intr.) New York, London, Toronto, Sydney: The Free Press.

Emmeche, Claus; Køppe, Simo; Stjernfelt, Frederik 2000. Levels, emergence, and three versions of downward causation. In: Andersen, Peter B.; Emmeche, Claus; Finnemann, Niels O.; Christiansen, Peder V. (eds.), Downward Causation: Minds, Bodies and Matter. Århus: Aarhus University Press, 13-34.

Emmeche, Claus; Kull, Kalevi (eds.) 2011. Towards a Semiotic Biology: Life is the Action of Signs. London: Imperial College Press. https://doi.org/10.1142/p771

Fauconnier, Gilles; Turner, Mark 2002. The Way We Think: Conceptual Blending and the Mind's Hidden Complexities. New York: Basic Books Inc.

Feierman, Jay R. 2013. Biology of religion. In: Runehov, Anne L. C.; Oviedo, Lluis (eds.), Encyclopedia of Sciences and Religions. Dordrecht, New York: Springer Reference, 257-259. https://doi.org/10.1007/978-1-4020-8265-8_135

Fisher, Simon E.; Ridley, Matt 2013. Culture, genes, and the human revolution. Science 340: 929-930. https://doi.org/10.1126/science.1236171

Frege, Gottlob 1960[1892]. On sense and reference. In: Geach, Peter; Black, Max (eds.), Translations from the Philosophical Writings of Gottlob Frege. Oxford: Basil Blackwell Publisher, 56-78.

Giorgi, Franco; Bruni, Luis E.; Maggio, Roberto 2010. Receptor oligomerization as a process modulating cellular semiotics. Biosemiotics 3(2): 157-176. https://doi.org/ 10.1007/s12304-010-9085-x 
Gleason, Andrew M. 1956. Finite Fano planes. American Journal of Mathematics 78(4): 797-807. https://doi.org/10.2307/2372469

Goudsmit, Arno L. 2007. Some reflections on Rosen's conceptions of semantics and finality. Chemistry \& Biodiversity 4(10): 2427-2435. https://doi.org/10.1002/cbdv. 200790198

Günther, Gotthard 1976. Formal logic, totality and the super-additive principle. Beiträge zur Grundlegung einer operationsfähigen Dialektik: Band 1: Metakritik der Logik, nichtaristotelische Logik, Reflexion - Stellenwerttheorie - Dialektik - Cybernetic ontology Morphogrammatik- Transklassische Maschinentheorie. Hamburg: Felix Meiner Verlag, 329-351.

Helmholtz, Hermann von 1977[1868]. On the origin and significance of the axioms of geometry. Epistemological Writings. Dordrecht: Reidel, 1-26. https://doi.org/10.1007/ 978-94-010-1115-0_1

Hoffmeyer, Jesper 2008. Biosemiotics: An Examination into the Signs of Life and the Life of Signs. Scranton: University of Scranton Press.

Kant, Immanuel (ed.) 1998[1781]. Critique of Pure Reason. Cambridge: Cambridge University Press.

Kauffman, Stuart A. 2008. Reinventing the Sacred: The Science of Complexity and the Emergence of a Natural Divinity. New York: Basic Books Inc.

Kercel, Stephen W. 2002. Endogenous causes - bizarre effects. Evolution and Cognition 8(2): 130-144.

Kilstrup, Mogens 2015. Naturalizing semiotics: The triadic sign of Charles Sanders Peirce as a systems property. Progress in Biophysics and Molecular Biology 119(3): 563-575. https://doi.org/10.1016/j.pbiomolbio.2015.08.013

Kineman, John J. 2012. R-theory: A synthesis of Robert Rosen's relational complexity. Systems Research and Behavioral Science 29(5): 527-538. https://doi.org/10.1002/ sres. 2156

Kodokostas, Dimitrios 2014. Proving and generalizing Desargues' two-triangle theorem in 3-dimensional projective space. Geometry: article ID 276108, 1-7. https://doi.org/ $10.1155 / 2014 / 276108$

Kotov, Kaie; Kull, Kalevi 2011. Semiosphere is the relational biosphere. In: Emmeche, Claus; Kull, Kalevi (eds.), Towards a Semiotic Biology: Life Is the Action of Signs. London: Imperial College Press, 179-194. https://doi.org/10.1142/9781848166882_0010

Kreinath, Jens 2006. Semiotics. In: Kreinath, Jens; Snoek, Jan A. M.; Stausberg, Michael (eds.), Theorizing Rituals: Issues, Topics, Approaches, Concepts. (Numen Book Series 114.1.) Leiden, Boston: Brill, 429-470. https://doi.org/10.1163/9789047410775_021

Kuhn, Thomas S. 1993. Metaphor in science. In: Ortony, Andrew (ed.), Metaphor and Thought. Cambridge, New York: Cambridge University Press, 533-542. https://doi. org/10.1017/CBO9781139173865.024

Kull, Kalevi; Emmeche, Claus; Hoffmeyer, Jesper 2011. Why biosemiotics? An introduction to our view on the biology of life itself. In: Emmeche, Claus; Kull, Kalevi (eds.), Towards a Semiotic Biology: Life Is the Action of Signs. London: Imperial College Press, 1-21. https://doi.org/10.1142/9781848166882_0001

Lakoff, George; Johnson, Mark 1980. Metaphors We Live by. Chicago, London: University of Chicago Press. 
Laland, Kevin N.; Matthews, Blake; Feldman, Marcus W. 2016. An introduction to niche construction theory. Evolutionary Ecology 30(2): 191-202. https://doi.org/10.1007/ s10682-016-9821-z

Leone, Massimo 2010. Saints and Signs: A Semiotic Reading of Conversion in Early Modern Catholicism. Berlin, New York: De Gruyter. https://doi.org/10.1515/9783110229523

Leone, Massimo 2014a. Religious conversion and semiotic analysis. In: Rambo, Lewis R.; Farhadian, Charles E. (eds.), The Oxford Handbook of Religious Conversion. Oxford: Oxford University Press, 369-400.

Leone, Massimo 2014b. Wrapping transcendence: The semiotics of reliquaries. Signs and Society 2(S1 / Supplement 2014): S49-S83. https://doi.org/10.1086/674314

Letelier, Juan C.; Marín, Gonzalo; Mpodozis, Jorge 2003. Autopoietic and $(M, R)$ systems. Journal of Theoretical Biology 222(2): 261-272. https://doi.org/10.1016/ S0022-5193(03)00034-1

Letelier, Juan-Carlos; Cárdenas, María L.; Cornish-Bowden, Athel 2011. From l'homme machine to metabolic closure: Steps towards understanding life. Journal of Theoretical Biology 286(1): 100-113. https://doi.org/10.1016/j.jtbi.2011.06.033

Lewontin, Richard C. 2000. The Triple Helix: Gene, Organism, and Environment. Cambridge: Harvard University Press.

Linden, Sandra 2011. Der inwendig singende Geist auf dem Weg zu Gott: Lyrische Verdichtung im Fließenden Licht der Gottheit Mechthilds von Magdeburg. In: Bleumer, Hartmut; Emmelius, Caroline (eds.), Lyrische Narrationen - Narrative Lyrik: Gattungsinterferenzen in der mittelalterlichen Literatur. (Trends in Medieval Philology 16.) Berlin, New York: De Gruyter, 359-386. https://doi.org/10.1515/9783110215922.359

Löh, Clara 2017. Geometric Group Theory: An Introduction. Cham, Switzerland: Springer Nature. https://doi.org/10.1007/978-3-319-72254-2_1

Lotman, Jurij M. 1990. Universe of the Mind: A Semiotic Theory of Culture. (Shukman, Ann, trans.; Eco, Umberto, ed.) Bloomington: Indiana University Press.

Lotman, Jurij M. 2005[1984]. On the semiosphere. Sign Systems Studies 33(1): 205-229.

Louie, Aloisius H.-Y. 2006. (M,R)-systems and their realizations. Axiomathes 16(1/2: Complex Systems Biology and Life's Logic. In Memory of Robert Rosen): 35-64. https://doi.org/10.1007/s10516-005-4203-0

Louie, Aloisius H.-Y. 2013. The Reflection of Life: Functional Entailment and Imminence in Relational Biology. New York, Heidelberg, Dordrecht, London: Springer.

Luhmann, Niklas 1992. What is communication? Communication Theory 2(3): 251-259. https://doi.org/10.1111/j.1468-2885.1992.tb00042.x

Luhmann, Niklas 1995. Social Systems. Stanford: Stanford University Press.

Luhmann, Niklas 2006. System as difference. Organization 13(1): 37-57. https:/doi. org/10.1177/1350508406059638

Luhmann, Niklas 2012[1997]. Theory of Society: Volume 1. Stanford: Stanford University Press.

Luhmann, Niklas 2013. A Systems Theory of Religion. Stanford: Stanford University Press.

Martin, Luther H.; Wiebe, Donald (eds.) 2017. Religion Explained? The Cognitive Science of Religion after Twenty-Five Years. London, Oxford, New York, New Delhi, Sydney: Bloomsbury Publishing.

Mechthild von Magdeburg 1869. Offenbarungen der Schwester Mechthild von Magdeburg: Oder das fliessende Licht der Gottheit. Regensburg: Verlag von Georg Joseph Manz. 
Mechthild von Magdeburg 2003. Selections from the Flowing Light of the Godhead. Translated from the Middle High German with introduction, notes, and interpretive essay by Elizabeth A. Andersen. Cambridge, Rochester: Boydell \& Brewer Inc.

Merrell, Floyd 1997. Peirce, Signs, and Meaning. Toronto, Buffalo: University of Toronto Press. https://doi.org/10.3138/9781442678330

Murphy, Tim 2003. Elements of a semiotic theory of religion. Method \& Theory in the Study of Religion 15(1): 48-67. https://doi.org/10.1163/15700680360549411

Nemes, Balázs J. 2012. Der involvierte Leser: Immersive Lektürepraktiken in der spätmittelalterlichen Mystikrezeption. Zeitschrift für Literaturwissenschaft und Linguistik 42(3): 38-62. https://doi.org/10.1007/BF03379686

Nöth, Winfried 2006. Yuri Lotman on metaphors and culture as self-referential semiospheres. Semiotica 161(1/4): 249-263. https://doi.org/10.1515/SEM.2006.065

Pagel, Mark 2017. Darwinian perspectives on the evolution of human languages. Psychonomic Bulletin \& Review 24(1): 151-157. https://doi.org/10.3758/s13423-016-1072-z

Parmentier, Richard J. 1994. Signs in Society: Studies in Semiotic Anthropology. Bloomington: Indiana University Press.

Peirce, Charles S. 1994. The Collected Papers of Charles Sanders Peirce. (Hartshorne, Charles; Weiss, Paul; Burks, Arthuyr W., eds.) Charlottesville: InteLex Corporation. [In-text references are to CP, followed by volume and paragraph numbers.]

Polster, Burkard 1998. A Geometrical Picture Book. New York: Springer. https://doi. org/10.1007/978-1-4419-8526-2

Queiroz, João; El-Hani, Charbel N. 2006. Semiosis as an emergent process. Transactions of the Charles S. Peirce Society 42(1): 78-116. https://doi.org/10.1353/csp.2006.0013

Richerson, Peter J.; Boyd, Robert J. 2005. Not by Genes Alone: How Culture Transformed Human Evolution. Chicago: University of Chicago Press. https://doi.org/10.7208/ chicago/9780226712130.001.0001

Rosen, Robert 1991. Life Itself: A Comprehensive Inquiry into the Nature, Origin, and Fabrication of Life. New York: Columbia University Press.

Salthe, Stanley N. 1985. Evolving Hierarchical Systems: Their Structure and Representation. New York: Columbia University Press. https://doi.org/10.7312/salt91068

Salthe, Stanley N. 1993. Development and Evolution: Complexity and Change in Biology. Cambridge: MIT Press. https://doi.org/10.7551/mitpress/8255.001.0001

Saussure, Ferdinand de 2011[1916]. Course in General Linguistics. (Baskin, Wade, trans.; . Meisel, Perry; Saussy, Haun, eds.). New York: Columbia University Press.

Schütz, Alfred; Luckmann, Thomas 2003[1979]. Strukturen der Lebenswelt. Stuttgart: UVK Verlagsgesellschaft.

Short, Thomas L. 2007. Peirce's Theory of Signs. Cambridge, New York: Cambridge University Press.

Spencer-Brown, George 1979[1969]. Laws of Form. New York: Dutton.

Taborsky, Edwina 2003. The six semiosic predicates. Semiotics, Evolution, Energy, and Development 3(2): 5-23.

Tononi, Giulio 2012. Phi: A Voyage from the Brain to the Soul. New York: Pantheon.

Toth, Alfred 2008. Semiotische Strukturen und Prozesse. Klagenfurt: IFF-Arbeitsbereich 'Technik- und Wissenschaftsforschung.' 
Uexküll, Jakob J. von 2014[1921]. Umwelt und Innenwelt der Tiere. (Mildenberger, Florian; Herrmann, Bernd, eds.) Berlin, Heidelberg: Springer.

Velmezova, Ekaterina; Kull, Kalevi; Cowley, Stephen J. (eds.) 2016. Biosemiotic Perspectives on Language and Linguistics. Cham: Springer International Publishing. https://doi. org/10.1007/978-3-319-20663-9

Walther, Elisabeth 1979[1974]. Allgemeine Zeichenlehre: Einführung in die Grundlagen der Semiotik. Stuttgart: Deutsche Verlagsanstalt.

Wilkins, Leanne K.; Girard, Todd A.; Cheyne, James A. 2011. Ketamine as a primary predictor of out-of-body experiences associated with multiple substance use. Consciousness and Cognition 20(3): 943-950. https://doi.org/10.1016/j.concog.2011.01.005

Wilson, Edward O. 1999[1998]. Consilience: The Unity of Knowledge. New York: Vintage Books.

Witzany, Günther 2010. Biocommunication and Natural Genome Editing. Dordrecht: Springer Netherlands. https://doi.org/10.1007/978-90-481-3319-2

Wolinsky, Emma; Libby, Eric 2016. Evolution of regulated phenotypic expression during a transition to multicellularity. Evolutionary Ecology 30(2): 235-250. https://doi. org/10.1007/s10682-015-9814-3

Yelle, Robert A. 2013. Semiotics of Religion: Signs of the Sacred in History. London, New York: Bloomsbury Academic.

Yelle, Robert A. 2017. Semiotics. In: Stausberg, Michael; Engler, Steven (eds.), Oxford Handbook of the Study of Religion. London, New York: Oxford University Press, 208-219. https://doi.org/10.1093/oxfordhb/9780198729570.013.15

Yockey, Hubert P. 2000. Origin of life on earth and Shannon's theory of communication. Computers \& Chemistry 24(1): 105-123. https://doi.org/10.1016/S0097-8485(00)80010-8

\section{Что можно перенять из семиотики, теории систем и теоретической биологии, чтобы понять религиозную коммуникацию}

Если религия, как социокультурная знаковая система является частью социокультурной сферы, то каким образом это сочетается с происходящими в религиозной среде духовными, органическими и физическими процессами? С помощью семиотики, теории систем и теоретической биологии данная статья пытается ответить на этот вопрос. Отправной точкой является понимание религиозной эволюции как сопутствующей (co-evolution) общественной эволюции. Общественная эволюция, в свою очередь, является коэволюцией духовной, органической и физической эволюции. Чистое состояние (eigenstate) социокультурной сферы заключается в языке, активированном через коммуникацию. Язык является репликатором общественно-культурных процессов, что соответствуют функции геномы в органических процессах. Различение сфер общей эволюции касается органического, духовного и социокультурного субстратов, в то время как нейтральная по отношению к субстрату структура двух эволюционных измерений органических и общественных процессов проявляется в разделяемых семиотических паттернах. Органические и религиозные процессы генерирования информации изоморфны. Таким образом семиозис опосредует религиозную коммуникацию и ее окружающую среду. 


\section{Mida võime õppida semiootikast, süsteemiteooriast ja teoreetilisest bioloogiast, mõistmaks religioosset kommunikatsiooni}

Kui religioon on ühiskondlik-kultuuriline tähendussüsteem osana ühiskondlik-kultuurilisest sfäririst, siis kuidas seostub see religiooni keskkonda kuuluvate vaimsete, orgaaniliste ja füüsiliste protsessidega? Artikkel aitab selle küsimusele vastata, osutades semiootikale, süsteemiteooriale ja teoreetilisele bioloogiale. Lähtepunktiks on religioosse evolutsiooni mõistmine ühiskondliku evolutsiooni koevolutsioonina, nimelt ühena viimase sisemistest alljaotustest. Ühiskondlik evolutsioon on omakorda vaimse, orgaanilise ja füüsilise evolutsiooni koevolutsioon. Need evolutsioonisfäärid moodustavad vastastikku üksteise keskkondi. Ühiskondlik-kultuurilise sfääri eigenstate seisneb kommunikatsiooni kaudu aktiveeritud keeles. Keel on ühiskondlik-kultuuriliste protsesside replikaator, mis vastab genoomi funktsioonile orgaanilistes protsessides. Üldevolutsiooni sfääride eristamine puudutab vastavat orgaanilist, vaimset ja ühiskondlik-kultuurilist substraati, samas kui orgaaniliste ja ühiskondlike protsesside kahe evolutsioonilise mõõtme substraadineutraalne struktuur tuleb ilmsiks jagatud semiootilistes mustrites. Informatsiooni genereerimise orgaanilised ja religioossed protsessid on isomorfsed. Seega vahendab semioos religioosset kommunikatsiooni ja selle keskkonda. 